\title{
Spontanous Human Combustion-are the Microzymas the Culprit?
}

\section{ISSN : 2688-836X}

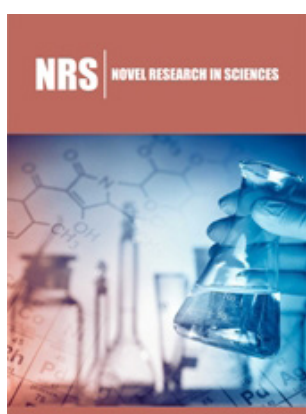

*Corresponding author: Mister Seun Ayoade, Independent Resesarcher, Nigeria

Submission: 海June 01, 2019

Published: 眥July 11, 2019

Volume 1 - Issue 2

How to cite this article: Mister S A. Spontanous Human Combustion-are the Microzymas the Culprit?. Nov Res Sci.1(2). NRS.000509.2019.

DOI: 10.31031/NRS.2019.1.000509

Copyright@ Mister Seun Ayoade,, This article is distributed under the terms of the Creative Commons Attribution 4.0 International License, which permits unrestricted use and redistribution provided that the original author and source are credited.

\author{
Mister Seun Ayoade* \\ Independent Resesarcher, Nigeria
}

\section{Introduction}

Spontaneous human combustion is a contentious and extremely rare phenomenon whereby a person suddenly bursts into flames or catches on fire without any visible external stimuli such as petrol and matches etc. being applied to the person. The victim often burns to ashes, yet the surroundings remain unburnt/unscorched/unscathed and the fire is promptly extinguished as miraculously as it started! Could there be a rational, scientific explanation for these freaky fires, scores of which have been documented in the last half millennium? Skeptics of this phenomenon a bound and some cases attributed to spontaneous human combustion have been argued to be due to concealed cigarette butts etc. But not all cases of this phenomenon can be so readily dismissed [1-4].

Picture a spherical living entity, too small to be seen by the naked eye. A living entity smaller than bacteria, viruses, red blood cells, white blood cells, fungi and protozoa. These living motile entities cannot be destroyed by any means yet devised by man. They are found in all living things-human beings, plants, dogs, lions, ostriches, giraffes etc. Once it's alivethe entity is found therein. These entities are found in the air also. These entities sometimes come together in groups and clumps and form bacteria. In greater agglutinations they form cells and tissues. And surprisingly when an animal or human being ceases to exist, these tiny bodies continue to live! Welcome to the world of the microzymas also known as cellular dust [5-7] theorized to be the creators of life on earth, and of the entire universe [8].

Under normal circumstances, heat in the human body is produced by basic metabolic processes, specific dynamic action and muscular activity. Heat is lost from the body by radiation, conduction, sweat vaporization, respiration and urination. It could very well be that in rare instances microzyma carry out some extremely exothermic reactions for which tissue conductance is hopelessly inadequate, and thus the cells, tissues, organs and systems literally burn up! The death of the unfortunate individual coincides with the de-coordination of the microzyma and that explains why the fire doesn't affect inanimate objects around the victim to an appreciable degree.

Barring ketosis, the wick effect, ball lightning and supernatural forces, microzyman reactions gone awry i.e. "rogue" microzymas might prove to be a rational explanation for the very perplexing spectacle called spontaneous human combustion..

\section{References}

1. Spontaneous human combustion, homicide, suicide or household accident Florica Mekereş, Camelia Liana Buhaș.

2. Rolli (1746) An Extract, by Mr. Paul Rolli FRS of an Italian Treatise, written by the Reverend Joseph Bianchini, a Prebend in the City of Verona; upon the Death of the Countess Cornelia Zangari \& Bandi, of Cesena. Philosophical Transactions. Royal Society (476): 447.

3. Thurston, Gavin (1938) Spontaneous human combustion. The British Medical Journal 1(4041): 1340.

4. Irishman died of spontaneous human combustion, coroner claims.

5. Mister S (2017) Koch's postulates and germ terrain dualism; cellular dust as yet another term for microzymas. J0J Nurse Health Care 5(4): 555666. 
6. Mister S (2017) The differences between the germ theory, the terrain theory and the germ terrrain duality theory. JOJ Nurse Health Care 4(2): 555631.

7. Seun A (2018) A new origin of life and the universe proposedmicrozymian!. Peer Re J Foren \& Gen Sci 1(5).
8. Seun A (2019) The cellular dust hypothesis and the laws of thermodynamics. Glob J Anes \& Pain Med 1(2).

For possible submissions Click below: 